Gazi University
Journal of Science
http://dergipark.gov.tr/gujs

\title{
Optimizing Urban Texture and Building Typology for the Goal of Achieving Near-Zero Mid-Rise Residential Building
}

\author{
Halit BEYAZTAS ${ }^{1, *}$, Gul Koclar ORAL ${ }^{2}$ \\ ${ }^{1}$ Istanbul Technical University, Graduate School of Science Engineering and Technology, 34496 Istanbul, Turkey \\ ${ }^{2}$ Istanbul Technical University, Department of Architecture, 34437, Istanbul, Turkey
}

Highlights

- Proposed optimized alternative achieves up to $69.1 \%$ of zero energy target.

- Urban texture has an effect up to $33.49 \%$ on building energy production performance.

- Urban texture has an effect up to $5.65 \%$ on building energy consumption performance.

\section{Article Info}

Received: $10 / 12 / 2019$

Accepted: 26/03/2020

Keywords

Urban texture

Building typology

Near-Zero energy

Building energy

simulation

\begin{abstract}
Turkey is experiencing a massive urban renewal process to increase earthquake resistance of building mass. As a participant of Paris Agreement, Turkey also uses this process as a tool to improve energy saving performance of building mass with mandatory insulation requirements. Envelope retrofits achieves energy savings; however, this massive urban renewal process offers a greater potential since it allows a chance to optimize urban scale variables such as urban texture and building type, as well. This paper focuses on investigating the influence of building typology and urban texture on building energy performance. For this purpose, four different texture and six different building type alternatives are defined in Istanbul. Energy performance simulation analysis of 24 total alternatives are done with Existing envelope, TS-825 envelope, and proposed Near-Zero envelopes. Results of 72 simulations show that both building type and urban texture have important influence on building energy consumption and production performances for three envelope alternatives. Selection of optimized building type and urban texture alternatives with $\mathrm{N}$-zero envelope maximizes building energy performance and achieve near-zero building requirements. Another important result of the study was urban scale decisions reduces energy consumption very significantly even before applying building design strategies. This is a very important input for decision-makers because energy performance of a regular building can be improved with retrofits in any time during lifetime. However, these retrofits may not be enough to achieve full potential (net-zero in future time) of the building when urban texture and building type is not optimized accurately.
\end{abstract}

\section{INTRODUCTION}

Built environment in the world is changing slowly and securely toward sustainable form [1-3]. The speed of change is very high in Turkey with a different motivation. Over $66 \%$ of Turkey's population lives in first and second-degree earthquake zones and the population increases every year [4]. Unfortunately, existing building stock is very vulnerable to earthquake forces, which caused 597.865 heavy housing damage and 86.802 death in Turkey since 1900 [5]. Estimations of three different institution shows that economic cost of 1999 earthquake alone is between 12-19 billion dollars [6]. Earthquake simulation models show that about $7.1 \%-8.2 \%$ of buildings would be damaged heavily in Istanbul [7]. These facts forced a major urban renewal process and 480.000 residential unit is already renewed between 2012-2017. It is targeted to renew total of 7.5 million residential unit in 15 years and 4 million of them is considered to be renewed by 2023 due to risk factor [8]. In other words, this renewal process transformed and will be transforming Turkish cities for a few decades. 
This costly but mandatory change offers Turkey great opportunities to convert its built environments and cities to sustainable ones. There is a need for strong political will to change toward sustainable future. In fact, Turkey is a net energy importer country and it imports over 75\% of its energy [9]. Energy balance shows that buildings consume 34.55 percent of energy in Turkey [10]. Therefore, every step toward sustainability is very welcome by the government since it reduces energy cost. Besides, signing Paris Climate Agreement indicates that there is also a political will to support this transformation. In fact, one of the promises that Turkey made in the Paris Conference was to disseminate the idea of Zero-energy house [11]. Necessary steps toward sustainability, including energy efficiency, renewable energy infrastructure, and low carbon emission, take place in national development plans $[12,13]$. Simultaneously, required law amendments is completed [14-16]. Literature evaluates the process and confirms existence of evidence toward sustainable transformation of built environment in Turkey. In 2005, Kocabas describes this urban renewal process as 5.period of urban regeneration in Istanbul and this period is expected to be a transient period to sustainable urban regeneration along with disaster prevention aim [17]. By 2011, evaluation of transition performance of Turkey to low carbon urbanization concludes that there is a positive initial steps with supporting policies toward this goal, but it requires continues action [18]. Following up the process to 2019, development plan of Turkey and fiscal report indicates that tax regulations on energy saving and climate change will continue [19]. State development plan for 2019-23 highlights the importance of sustainable urban development and lists the steps toward this goal including energy efficiency, renewable energy production, and green building concepts [20].

Renewal process in Turkey takes place both on neighborhood and parcel scales. Literature mainly focuses on neighborhood scale renewal, which is mainly done by TOKİ (Housing Development Administration of Turkey). Improved living conditions of residents are considered positive outcome of the process [21,22]. Despite the disaster resistant new buildings, gentrification concerns and change of social life conditions are considered negative consequences [23-25]. From energy standpoint, new buildings have to comply new Turkish building insulation standard (TS-825), which is a mandatory regulation since 2008 [26]. As of 2017, 677.000 buildings complies with the energy performance requirements and $2.97 \%$ of this buildings uses renewable energy resources [27]. In other words, reconstructed buildings are energy efficient comparing to deconstructed ones. Besides, they generate their energy up to certain percent. Mangan and Oral investigates energy performance of a new low income public mass housing neighborhood developed by TOKI as a case study for different climates of Turkey. Comparing to reference building, their study of life cycle assessment, life cycle cost, and life cycle $\mathrm{CO} 2$ assessment show that there are more space for cost optimized improvements to make buildings more energy efficient [28]. A step further, Kalaycioglu and Y1lmaz test energy performance potential of a virtual neighborhood district for nearly zero definition against EPBD recast requirements. Simulation result of different design packages shows that almost $70 \%$ of energy saving is possible in Eskişehir, Turkey [29]. So far, these are focused on neighborhood scale energy performance analysis.

Second type renewal takes place on parcel scale, called on-site renewal (Figure 1). Local municipals are given power to propose renewal areas to the ministry of Environment, in order to fasten renewal process. Residents of a building in renewal areas can apply renewal process. In order to encourage urban renewal, municipalities increase building height limits in renewal areas. As a result, old buildings are reconstructed with add-on floors, mostly these floors finance reconstruction costs and profit of the builder. System is economically sustain itself. However, this changes the urban texture and identity of the area (Figure 2).

Existing apartment texture evolves to midrise buildings that forms urban canyons (Figure 2). Urban canyons affect energy behavior of buildings. In high dense settlements, buildings may serve as obstacles to solar radiation and daylight availability depending on the distances between them, their height and their arrangement with respect to one another. In other words, density causes climate change in micro scale [30]. Such settlements lead to more energy consumption [31,32]. Additionally, urban density will reduce wind circulation in the city, so buildings will be more dependent on artificial systems for air circulation and cooling, especially the lower floors [33]. A study on 10 different canyons of Athen shows that air flow rates may be reduced 10 times inside of an urban canyon [34]. Moreover, urban density will closely affect renewable energy potentials of urban units [35]. Besides, it is closely related to outdoor thermal comfort [36-38]. 

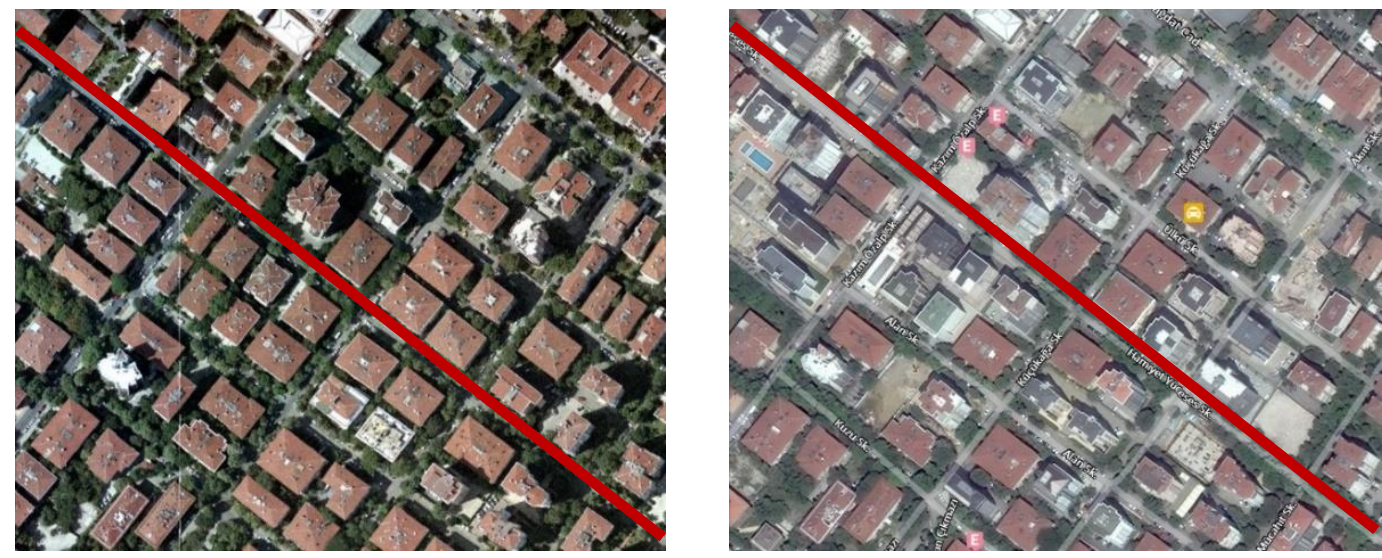

Figure 1. Texture change of Suadiye neighborhood, Kadıköy in 2006 (left) and 2017(right), Hamiyet Yüceses Street is marked on the figure
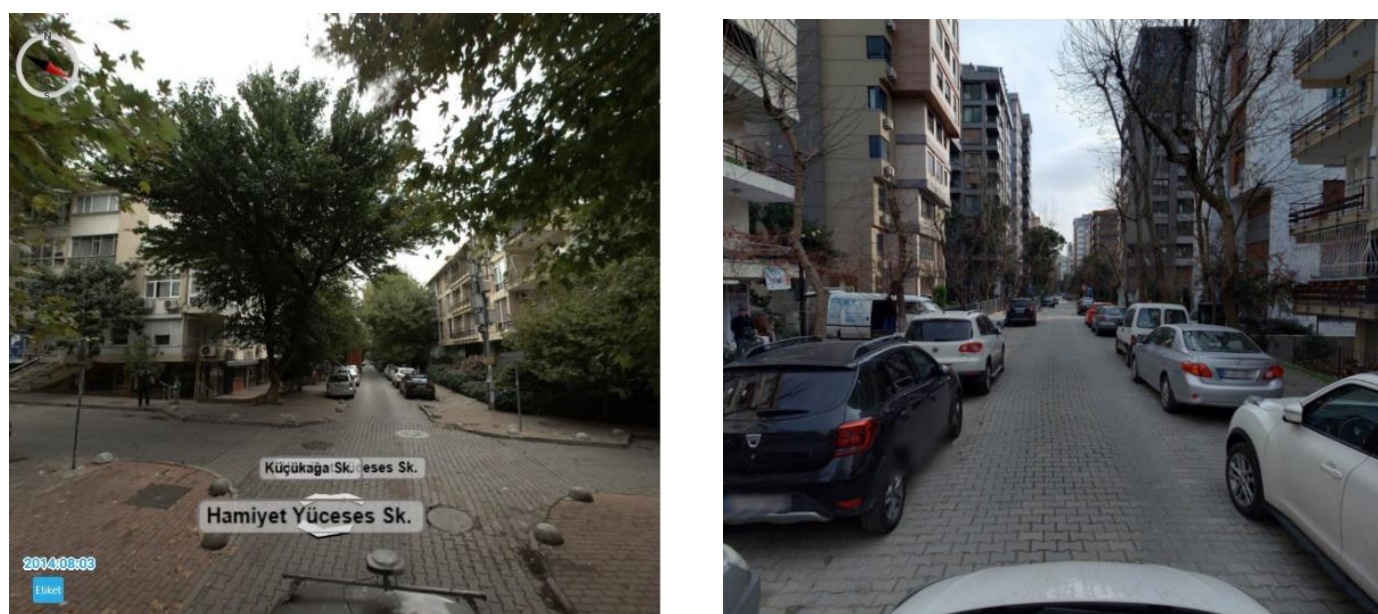

Figure 2. Street view of Hamiyet Yüseces Street, Kadlköy in 2014(on the left) and 2018(on the right)

Another factor that this urban renewal process needs to address is urban heat island effect. Half of the world population lives in urban area since 2008 [39], and it is projected to reach 67\% by 2050 [40]. Microclimatic conditions of urbanized area changes comparing to surrounding area due to urban heat island effect [41]. Urban heat island effect increases building energy consumption [34, 42-44]. Urban texture is an effective tool to mitigate urban heat island effect. Building types forms urban textures and urban textures generates urban characteristics. Urban renewal process provides an opportunity to retrofit both a single building and urban texture simultaneously. The important question, in terms of Turkey which is under intense process of urban renewal, is that 'how parcel based renewal will influence the overall goal of achieving zero energy building of Turkey?' What is the most energy efficient urban texture? What kind of residential building type improves building energy performance? This study focuses on finding most energy efficient urban texture.

\subsection{Urban characteristic and Energy performance}

Achieving environmentally sustainable urban renewable process requires the transformation of each and every existing building types to a zero energy or near zero energy building. It is a significantly new approach to consider building typology as a tool for assessing building energy performance. Despite the fact that buildings have many different attributes, they can be categorized under a number of groups that performs similarly in terms of energy consumption behavior. This is more applicable for residential buildings. The time of construction, available material on the market during the construction period, available technique and technology of the time, socio-economic standard of the society, social expectations and aesthetics codes of that specific time period shapes characteristics of the building masses. These factors make distinct differences on built environment which leads to different residential types. European Union 
residential building typology project TABULA classifies building typologies of countries across the Europe [45]. It is also be considered as a platform that many studies built up on it.

Dascalaki and his team used 24 building types that has three different construction time period, two different sizes as single family and multi-family, and four different climates zones [46]. Standard case simulation results showed that of applying current national requirements of thermal insulation and solar collector for domestic hot water, utilizing energy efficient heat production unit and reducing heat distribution loses helps $15 \%$ of pre- 1980 building stock and 30\% of 1980-2000 building stock to achieve $9 \%$ of reduction by 2016 (date of the study 2011). This is one of the early studies that investigates the relationship between building type and energy performance. It concludes that building type is an effective tool for evaluating energy performance of large scale of building stock. Kragh and Wittchen developed two typology models for Danish building stock: real building and average design building models [47]. Total of three main building types (single-family houses, terraced houses, and blocks of flats) grouped under nine construction age periods. Based on average design building models, space heating balance model was developed. The energy calculation of space heating balance model has less than $4 \%$ difference comparing to statistical data. It is concluded that the tool is useful for scenario analysis. Ballarini and his team works on a project that quantifies energy saving potential of existing building stock by using reference building and synthetic average models [48]. For this purpose, 18 residential building types that represents residential building types of Piedmont region, are selected among TABULA residential building types of Italy. Selected types include six building age classes and three buildings sizes. Italian residential building typology defined as three climatic zones, eight building age classes and four building size types which are single family house, terrace house, multifamily house, and apartment blocks. The results show that the standard refurbishment package save 77\% energy compare to the existing case in Piedmont region while the advance refurbishment package saves up to $85 \%$ energy. Additional studies show that building typology can be used as a tool for estimating energy behavior of large building stocks [49,50]. Along with energy consumption performance, there would be a relationship between building type and building energy production potential. Building type influences roof formation and geometry. Roof geometry dictates the area for solar panel placement. In other words, it influences building energy production performance [51]. Similarly, building type forms facade geometry, which limits potential façade area for energy production. This results the fact that building type also influences building energy production potential [52,53].

\subsection{Zero Energy Concept}

Zero energy building concept is now becoming new normal for building codes of the time. Considering the fact that official definition of sustainability is accepted in 1987, a big and fundamental transformation is being achieved, so far. Combining environmental concerns with oil crisis led a search for new clean energy alternatives [54]. Now, zero energy buildings are operable in many part of the world. A step further is that existing building energy policies are evolving to zero or near-zero energy building policies in some part of the world $[55,56]$. California integrated energy policy report recommends achievement of net zero energy by 2020 for new constructed residential building and by 2030 for commercial buildings [57]. All new buildings in European Union zone are required to be nearly zero energy building by 2020 [58]. In the planning phase of new US federal buildings in 2020 will designed to be net zero energy buildings by 2030 [59]. Zero energy concept takes place in two main different forms: nearly zero energy and zero energy. In US regulations, zero energy concept takes place in net-zero energy building form and it is defined as annual source energy consumption of a building must be equal or less than generated on-site renewable energy amount [60]. On the other hand, EU directives addresses nearly-zero energy building. It is defined as meeting significant amount of energy need of a high performance building from on-site or nearby renewable resources [61].

\subsection{The purpose of the Study}

The purpose of this paper is to evaluate the potential of existing building mass for the goal of achieving near zero energy residential building. Near zero energy residential buildings are expected to generate the energy they need. Considering that Turkey has an important potential in terms of solar energy as a renewable energy source, it is possible to provide the energy needed by the buildings from the sun. The 
achievement of this objective is seen as more accessible, especially in low-density rural areas and detached houses. However, in big cities such as Istanbul in Turkey, urban textures generally consist of multi-storey and high density structures. Considering the fact that solar panels in residential settlements are placed on the roofs, solar energy per housing unit will decrease due to the increasing urban density, which will cause a decrease in energy production per square meter. This increases the importance of facades for energy production through solar panels. However, the increase in urban density and the shading of buildings will affect building energy consumption. In addition to urban density, building typology can have an impact on energy production and consumption potential. Therefore, an optimization study based on the energy consumption and production performance of the existing building mass is an important need for energy efficient and sustainable urban planning. Such studies become necessary for Turkey and especially in the rapidly changing due to the large urban building stock renewal process that took place in Istanbul and converted to a system of sustainable urban texture.

\section{METHODOLOGY}

This study aims to examine the relationship between urban texture and building energy consumption/production performance in order to maximize near zero energy potential of buildings and communities. Istanbul is selected as study area because of high number of building stock and rapid urban transformation activities. Existing urban texture and existing residential multifamily building typologies are investigated. Result of the investigation formed reference urban textures and reference residential building types. Reference buildings and textures are modeled with Openstudio software and EnergyPlus building energy simulation engine were used for energy calculations. Pilot studies showed that cost optimized zero energy high-rise multifamily residential building target is not possible with current technology; therefore, this study aims to focus on achievement target of cost optimized near zero multifamily building by following Energy Performance of Building Directive (EPBD) protocol of European Union [61]. Methodology section consists of four subsections: defining reference urban texture, defining reference building, near zero energy envelope alternative, and energy production. The detailed steps of the study are described below.

\subsection{Defining Urban Texture}

Defining current urban texture is one of the important parts of this study because there is not a detailed study that identifies existing urban textures of Istanbul. Istanbul is a very historical, dense, and big city; therefore, identifying existing urban textures of Istanbul is very difficult. Besides, the shanty settlement problem as a result of inner migration formed an undefined texture throughout Istanbul. The planning department of the city categories the existing urban texture under four main groups: historical texture, planned/organized texture, unplanned/unorganized texture(shanty settlements), and mass housing [62]. In this research, "planned/organized texture" is studied. The boundary of Kadıköy municipality includes good examples of planned urban textures. Thirty different street samples were studied in order to identify existing urban textures in Kadıköy. It is discovered that, depending on the building regulations of construction time, there are differences in building heights and the distance between neighboring buildings. However, a relationship is identified between the height and the distances to neighbor buildings. Despite the fact that the number of floors are varying, there are a big number of high-rise buildings, most of them are newer buildings with around 12-story building height. Therefore, 12-story (36.5 meters) was determined as reference building height for simulation model. Distances are varying between neighbor buildings, as well. The distance to neighbor building across the street (w1) is between $16 \mathrm{~m}$ and 28.5 meters while the distance to neighbor building across the back yard (w2) is between $16 \mathrm{~m}$ and 55.5 meters. It is identified that there are three kind of relationship between $w 1$ and $w 2$ values. The relationships are $w 1=w 2$ (which is named as small yard), $1.5 \mathrm{w} 1=\mathrm{w} 2$ (which is named as medium yard), and $2 \mathrm{w} 1=\mathrm{w} 2$ (which is named as large yard). The small and large yards are presented in Table 1.

$$
\begin{aligned}
& 28.5 \mathrm{~m}>=\mathrm{w}_{1}>=16 \mathrm{~m}, \\
& 55.5 \mathrm{~m}>=\mathrm{w}_{2}>=16 \mathrm{~m},
\end{aligned}
$$




$$
\begin{aligned}
& \text { Ratio }=\left\{\mathrm{h} / \mathrm{w}_{1} \mid 28.5 \mathrm{~m}>=\mathrm{w}_{1}>=16 \mathrm{~m}\right\} \\
& \mathrm{h} / \mathrm{w}_{1}=\{1.3,1.4,1.5, \ldots, \text { and } 2.3\} .
\end{aligned}
$$

In Equation (1), $\mathrm{w}_{1}$ stands for measured distance to neighbor building across the street. In Equation (2), $\mathrm{w}_{2}$ stands for measured distance to neighbor building across the backyard. The minimum and maximum distance of $\mathrm{w}_{1}$ and $\mathrm{w}_{2}$ is defined based on street data. In Equation (3), h refers to the building height, which is 36.5 meters. In Equation (4), possible $\mathrm{h} / \mathrm{w}_{1}$ ratios are defined.

\begin{tabular}{|c|c|c|c|c|c|c|c|c|c|c|c|c|}
\hline & \multicolumn{11}{|c|}{$\mathbf{h} / \mathbf{w}_{\mathbf{1}}$} \\
\hline & & 1.3 & 1.4 & 1.5 & 1.6 & 1.7 & 1.8 & 1.9 & 2 & 2.1 & 2.2 & 2.3 \\
\hline \multirow{2}{*}{$\begin{array}{c}\mathbf{w}_{\mathbf{1}}=\mathbf{w}_{\mathbf{2}} \\
\text { (Small Yard) }\end{array}$} & $\mathrm{w}_{1}$ & $28 \mathrm{~m}$ & 26 & 24 & 23 & 21 & 20 & 19 & 18 & 17 & 17 & $\underline{16 \mathrm{~m}}$ \\
\hline & $\mathbf{w}_{\mathbf{2}}$ & $\overline{28 \mathrm{~m}}$ & 26 & 24 & 23 & 21 & 20 & 19 & 18 & 17 & 17 & $\overline{16 \mathrm{~m}}$ \\
\hline \multirow{2}{*}{$\begin{array}{l}\mathbf{1 . 5} \mathbf{w}_{\mathbf{1}}=\mathbf{w}_{\mathbf{2}} \\
(\text { Mid. Yard) }\end{array}$} & $\mathbf{w}_{1}$ & 28 & 26 & 24 & 23 & 21 & 20 & 19 & 18 & 17 & 17 & 16 \\
\hline & $\mathbf{w}_{2}$ & 42 & 39 & 37 & 34 & 32 & 30 & 29 & 27 & 26 & 25 & 24 \\
\hline \multirow{2}{*}{$\begin{array}{c}\mathbf{2} \mathbf{w}_{\mathbf{1}}=\mathbf{w}_{\mathbf{2}} \\
(\text { Large Yard) }\end{array}$} & $w_{1}$ & $28 \mathrm{~m}$ & 26 & 24 & 23 & 21 & 20 & 19 & 18 & 17 & 17 & $\underline{16 m}$ \\
\hline & $\mathbf{w}_{\mathbf{2}}$ & $56 \mathrm{~m}$ & 52 & 49 & 46 & 43 & 41 & 38 & 37 & 35 & 33 & $32 \mathrm{~m}$ \\
\hline
\end{tabular}

Table 1. Identifying all possible $w_{1}$ and $w_{2}$ distances based on $h / w_{1}$ ratios

All possible distances between buildings calculated and 30 different $\mathrm{w}_{1}$ and $\mathrm{w}_{2}$ combinations presented in Table 1. In this study, minimum (1.3) and maximum (2.3) $\mathrm{h} / \mathrm{w}_{1}$ ratios for small and large yard alternatives will be focused (marked on the table above). In order to simplify, each distance type named as A, B, C, and D-distances and illustrated in Table 2.

\begin{tabular}{|c|c|c|}
\hline Type & $\mathbf{h} / \mathbf{w}_{1} \quad$ Ratio & $\mathbf{w}_{2} / \mathbf{w}_{1} \quad$ Ratio \\
\hline A-distance & 2.3 (minimum) & 1 (Small Yard) \\
\hline B-distance & 1.3 (maximum) & 1 (Small Yard) \\
\hline C-distance & 2.3 (minimum) & 2 (Large Yard) \\
\hline D-distance & 1.3 (maximum) & 2 (Large Yard) \\
\hline
\end{tabular}

Table 2. Texture Characteristics

\subsection{Defining Residential Building Types}

Evaluation of residential building types results that four common building types exist in Istanbul. Identified main building types could be defined as single standing (Single S.) apartment building which has an apartment on each floor, twin apartment(Twin) building which has two apartments on each floor, quadruple (Quad.) apartment building has four apartments on each floor, and row apartment (Row) buildings which has an apartment on each floor (Figure 3).
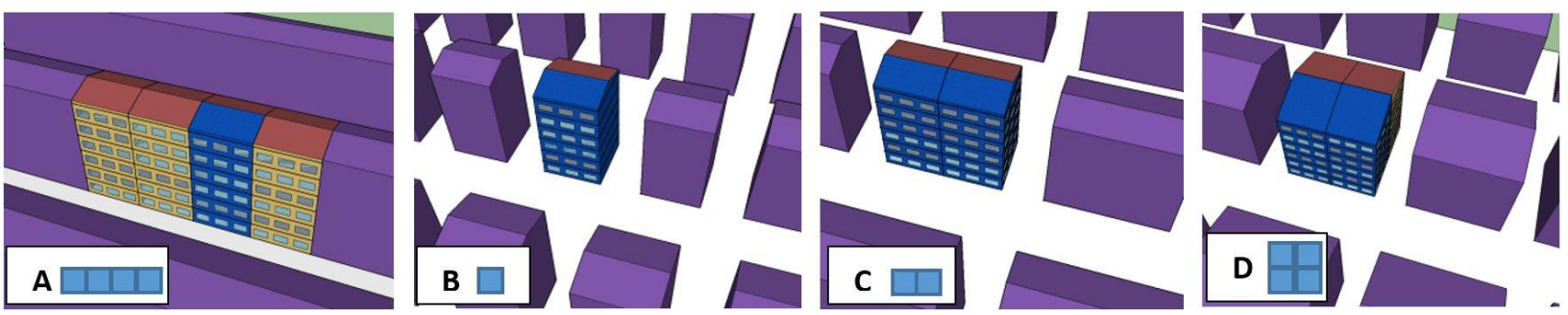

Figure 3. Illustration of building types: Row apartment (A) Single Standing $(B)$ Twin $(C)$ and Quadruple apartment buildings (D)

Buildings are oriented on cardinal directions; therefore, minimum a façade directed to the South. Each apartment has windows on two facades at least. For Twin apartment buildings, three different window orientation alternatives was developed: Twin-1: South and North, Twin-2: South, East, and West, Twin-3: South, North, and East or West. Only Twin-3 apartment units have windows on three facades (Table 3). As a result, six different building types identified and there are four different distance combination alternatives for each type. In total, 24 different urban textures identified. Each building type will be simulated for four different distance combinations (Figure 4). 
Table 3. Defined building types, facade numbers with window, window placements, and abbreviations

\begin{tabular}{|c|c|c|c|c|}
\hline $\begin{array}{c}\text { Residential Building } \\
\text { Type }\end{array}$ & Abb. & $\begin{array}{c}\text { Windows Numbers } \\
\text { per Apartment }\end{array}$ & $\begin{array}{c}\text { Windows Placement } \\
\text { on Facades }\end{array}$ & $\begin{array}{c}\text { Window Placement } \\
\text { and Orientation }\end{array}$ \\
\hline Single Standing & Single & 2 & South \& North & A \\
\hline Row Apartment & Row & 2 & South \& North & \\
\hline Twin-1 Apartment & Twin-1 & 2 & South \& North & 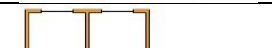 \\
\hline Twin-2 Apartment & Twin-2 & 2 & South, East, West & 7 \\
\hline Twin-3 Apartment & Twin-3 & 3 & $\begin{array}{l}\text { South, North, East, } \\
\text { West }\end{array}$ & $\stackrel{b}{\mathbb{V}}$ \\
\hline Quadruple Apart. & Quad. & 2 & $\begin{array}{c}\text { South, North, East, } \\
\text { West }\end{array}$ & \\
\hline
\end{tabular}
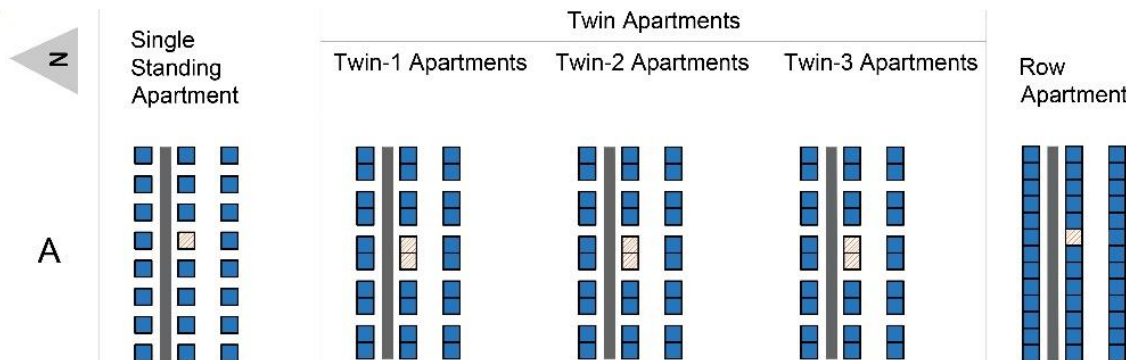

C
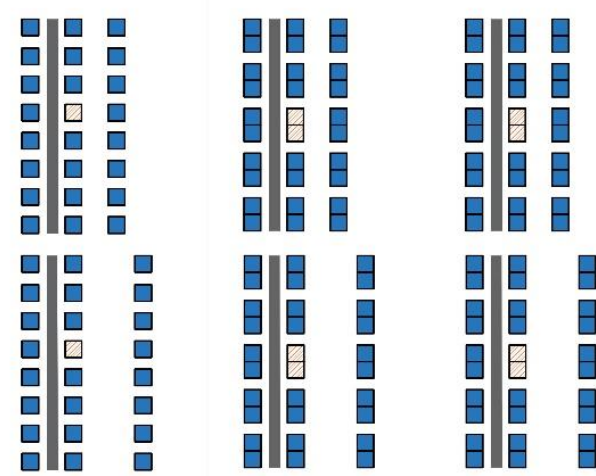

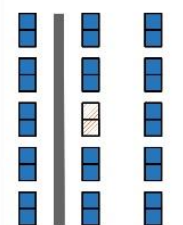

B

$\begin{array}{lll}\square & \square & \square \\ \square & \square & \square \\ \square & \square & \square \\ \square & \square & \square \\ \square & \square & \square \\ \square & \square & \square \\ \square & \square & \square \\ \square & \square & \square\end{array}$

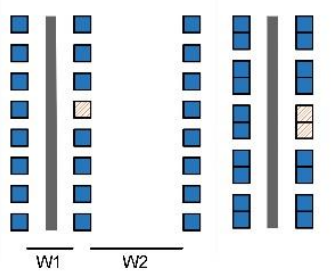

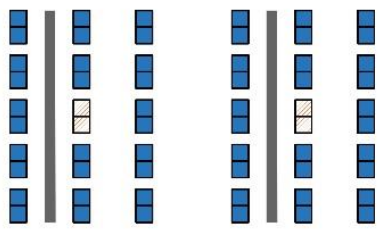
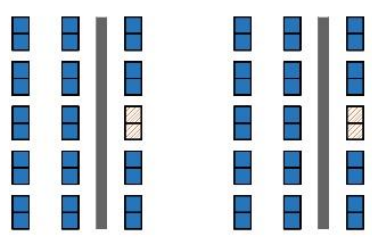
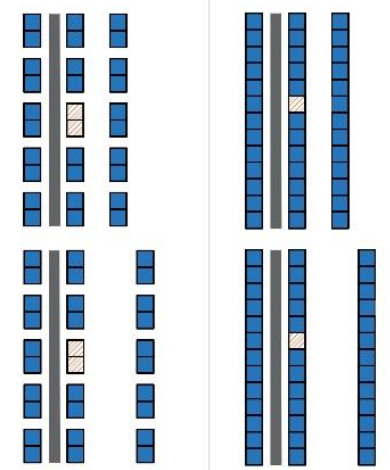

Quadruple

Apartment
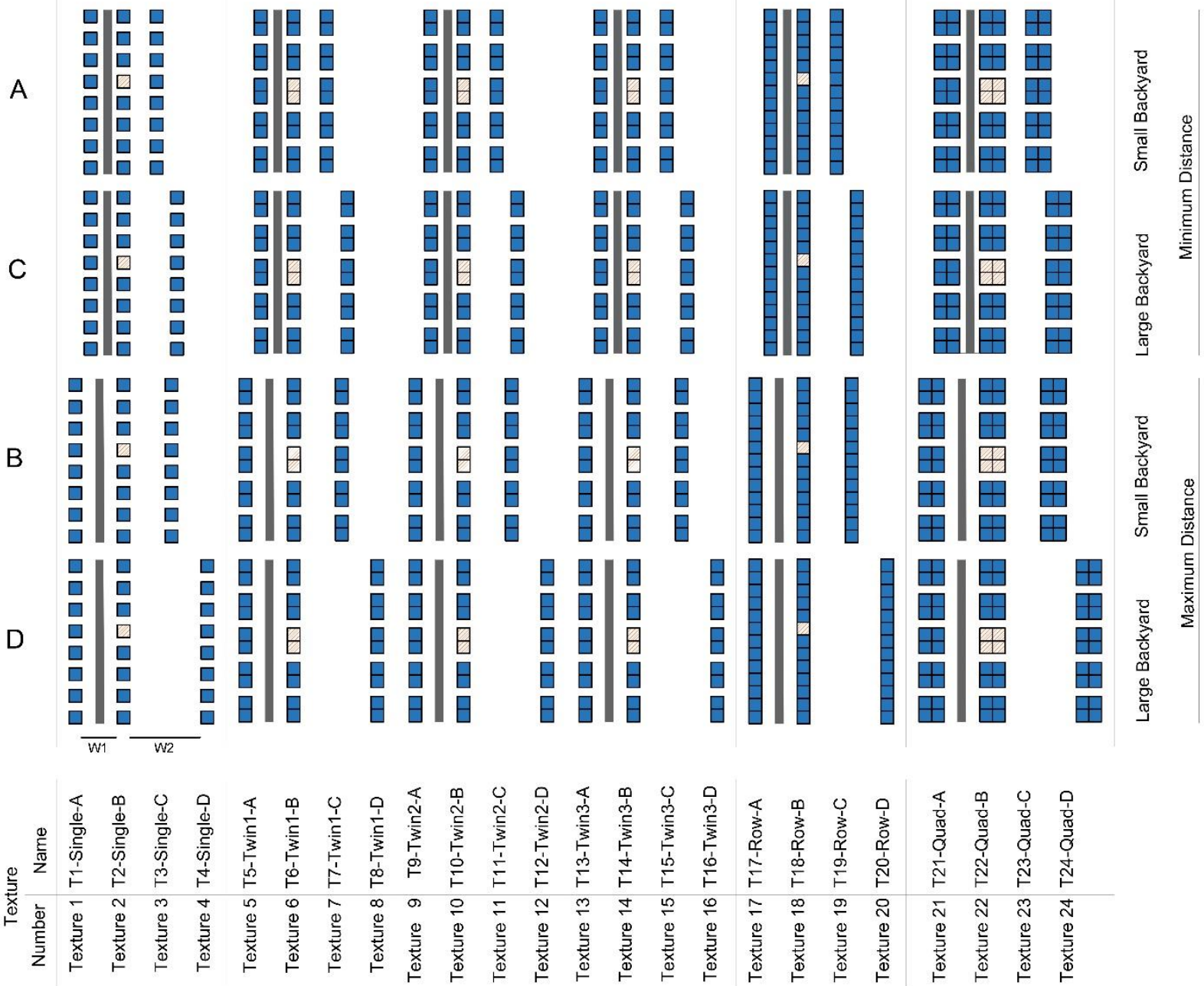

Figure 4. Illustration of 24 textures (Difference between Twin alternatives is window orientation) In row $A$ and row $B, w_{1}=w_{2}$; In row $C$ and row $D, 2 w_{1}=w_{2}$; On the other hand, $h / w_{1}$ ratio of row $A$ and $C$ is $2.3, h / w_{1}$ ratio of row $B$ and $D$ is 1.3 


\subsection{Defining Reference Building}

Reference building is a sample building that represents a large number of buildings. Therefore, it is a very useful tool to understand energy consumption behavior of large building stocks. Sufficiency of available statistical data determines the type of reference building, which could be a virtual model or a sample building. TABULA (Typology Approach for Building Stock Energy Assessment) project of European Union generates building typologies for each EU country [63]. In other words, the system defines reference buildings for each country. Unfortunately, Turkey is not a part of TABULA system but the existing statistical data helps to build up a framework of a virtual reference building. Virtual models used in several energy performance studies $[29,64]$. TABULA system and other studies in the literature mainly categorize buildings as building age, construction type, heating system and building geometry (form, size, etc.) [65]. These four categories will be used to define a reference building in Istanbul. The order is building age, construction type and material, building geometry definition, and HVAC system type definition.

Building age is the first parameter on defining reference building. Around $20 \%$ of Turkish residential units are located in Istanbul. Construction age of building stock for Istanbul and Turkey is presented in Table 4. Unknown category in the table would probably represent old village houses in rural areas, which is beyond the scope of this study. However, according to statistical data, significant percent of buildings are constructed since 1960s. Between 1961-2011, 87.7\% of building stock constructed in Istanbul and it is $84.6 \%$ for Turkey (Table 4). Moreover, important percent of this building stock is constructed after 1980s In other words, Turkey has a significantly young building stock. Due to inner migration, majority of building stock constructed lately in order to respond sheltering need quickly. Therefore, building age does not reveal very significant difference since construction technique and building characteristics did not changed very much in this period. However, it should be noted that building insulation regulation became mandatory in 2008. The effect of this regulation is investigated below construction and material subsection.

Table 4. Construction age of building stock (\%) [66]

\begin{tabular}{lcccccccc}
\hline & Unknown & Before 1960 & $\mathbf{1 9 6 1 - 7 0}$ & $\mathbf{1 9 7 1 - 8 0}$ & $\mathbf{1 9 8 1 - 9 0}$ & $\mathbf{1 9 9 1 - 0 0}$ & $\mathbf{2 0 0 1 - 1 1}$ & $\mathbf{1 9 6 1 - 2 0 1 1}$ \\
\hline Turkey & 11.3 & 4.2 & 5.9 & 13.4 & 18.9 & 24.6 & 21.8 & $\mathbf{8 4 . 6}$ \\
Istanbul & 10.2 & 2.1 & 5.1 & 14.5 & 21.1 & 29.1 & 17.9 & $\mathbf{8 7 . 7}$
\end{tabular}

Construction type and material is the second parameter on defining reference building. Construction type of residential buildings in Istanbul and Turkey are presented below (Figure 5) [66]. Eight different types are listed. Concrete frame structure with brick envelope is a very common construction type. $95.7 \%$ of building stock of Istanbul and 79.4\% of Turkish building stock have this type construction. Brick envelope consists of brick exterior wall covered with interior and exterior cement plaster. Old windows used to be wooden frame with single glass; however, these windows were replaced with PVC frame with double glazed windows for energy efficiency since early 2000s.

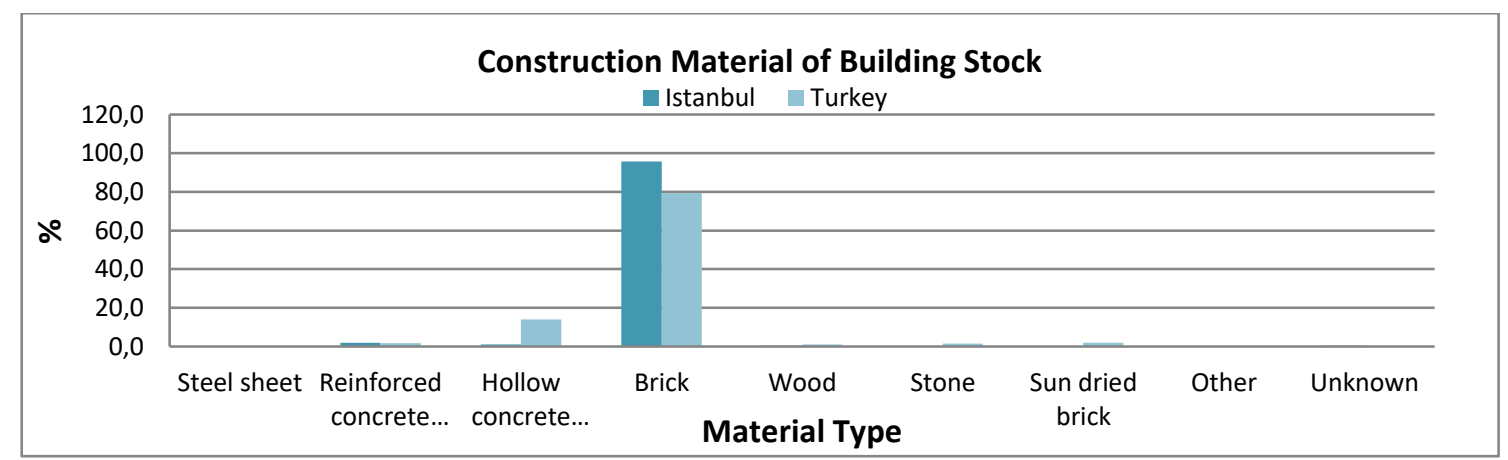

Figure 5. Construction material distribution of building stock of Istanbul (up to 2000) [66]

Prior to 2000s, many buildings did not have any insulation layer. New buildings have to meet TS-825 (Building Insulation Regulation) requirement. TS-825 defines the limits of U-values for five climate zones of Turkey [26]. Istanbul is located in Zone-2. In Zone-2, required maximum U-value for envelope wall is $0.57\left(\mathrm{~W} / \mathrm{m}^{2} \mathrm{~K}\right)$, foundation $\mathrm{u}$-value is $0.38\left(\mathrm{~W} / \mathrm{m}^{2} \mathrm{~K}\right)$, roof $\mathrm{U}$-value is $0.57\left(\mathrm{~W} / \mathrm{m}^{2} \mathrm{~K}\right)$, and window $\mathrm{U}$-value 
is $1.8\left(\mathrm{~W} / \mathrm{m}^{2} \mathrm{~K}\right)$. In other words, although construction type does not change significantly, there are two different envelope characteristic in terms of energy performance: Existing envelope and TS-825 standard compliance envelope. The only difference is that TS-825 envelope has additional envelope layer. To sum up, current building stock has two different envelope types: a) Existing envelope which has no insulation layer and b) TS-825 compliant envelope.

Building geometry is the third parameter on defining reference building. Building height and number of apartments on a floor are two important parameters that defines building geometry in Istanbul and Turkey. Building height differs very much in the country and within cities. Height change could also be observed in smaller scales as local municipalities, neighborhoods and streets. Rural areas are characterized by singlefamily housing; however, the dominant housing characteristic of urban area is multifamily residential apartment buildings. Building permits data reflects that $10+$ story buildings are the dominant character in Kadikoy area (Figure 6). This is compatible with the site findings, which is 12-story building height. Same statistics show that average building floor are for the same time period is 102 meter square.

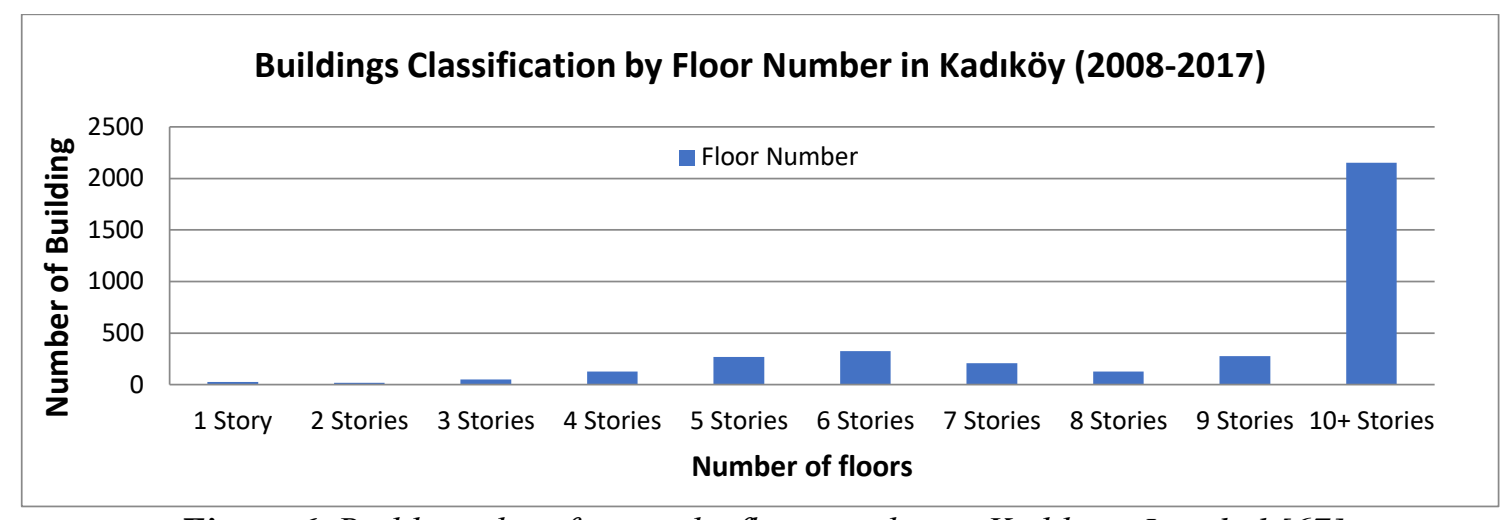

Figure 6. Building classification by floor number in Kadıköy -Istanbul [67]

HVAC system type is the fourth parameter on defining reference building. National statistics show that three main heating system is used in Turkey [66]. They are categorized as a) stove, b) central heating for one or more buildings and c) air conditioner, electric heater and other systems. 2011 dated statistics shows that $38.4 \%$ of residential buildings constructed after 2001 uses stove, while central heating for one or more buildings is $54.6 \%$ and the rest is $6.9 \%$ (Table 5). Central heating system with natural gas is the dominant heating system. Old buildings are replacing stove heating system with central heating system as natural gas infrastructure expands in Turkey. Besides, since 2010, it is mandatory to have central heating system for buildings that have over $2000 \mathrm{~m} 2$ floor area. As of 2017, natural gas infrastructure covers around $75 \%$ of population and $78.48 \%$ of people who has access the infrastructure uses natural gas [68]. This ratio is expected to be higher in metropolitan cities such as Istanbul; therefore, reference heating system is defined as water based radiator heated by natural gas.

Table 5. Heating system type distribution by construction time period (\%) in Turkey [66]

\begin{tabular}{rccc}
\hline & $\begin{array}{c}\text { Stove (natural gas stove } \\
\text { included). }\end{array}$ & $\begin{array}{c}\text { Central heating for one or } \\
\text { more buildings. }\end{array}$ & $\begin{array}{c}\text { Air conditioner, electric } \\
\text { heater and other systems. }\end{array}$ \\
\hline Between 1981-90 & 60.9 & 33.2 & 5.9 \\
Between 1991-00 & 50.8 & 42.1 & 7 \\
After 2001 & 38.4 & 54.6 & 6.9
\end{tabular}

\subsection{Near-Zero Energy Envelope Alternative}

Existing envelope is retrofitted to develop near zero energy envelope. This retrofitting procedure is done with cost optimization by applying EPBD protocol [61]. Firstly, envelope insulation thickness is defined according to cost optimization procedure. Energy savings of various XPS insulation layer products on the market (up to $15 \mathrm{~cm}$ thickness) are calculated via energy simulations. Maximum of net present value of the savings are calculated and compared. The optimum alternative is identified as near-zero insulation thickness. This procedure is done for optimizing exterior wall, roof, and foundation insulation thicknesses. 
Secondly, same procedure used for defining optimum glazing alternative. Five different glazing alternatives are used: double glazed with air, double glazed with argon, triple glazed with air, triple glazed with argon (in single gap), and triple glazed with argon (in two gaps). The optimum alternative is defined as triple glazed with argon (in two gaps). Lighting system is retrofitted with LED lighting system. Heating system is not changed because existing heating system in the country significantly new and average system on the market is used. Heating system is water-based radiator with natural gas heated. System performance of defined HVAC system is retrofitted to 4.5 COP. Lastly, exterior venation window blind is includes in south façade of near-zero building alternative. All envelope characteristics, including near-zero one, are documented in Table 6.

Table 6. Summary table of three different envelope characteristics and retrofits (Near-0 envelope is developed according to EPBD protocol [61])

\begin{tabular}{|c|c|c|c|}
\hline & Existing Envelope & TS-825 Envelope & Near-0 Envelope \\
\hline $\begin{array}{l}\text { Envelope Insulation Thickness } \\
\text { and U-values }\end{array}$ & Uwall: 1.30; No Insulation & $\begin{array}{l}\text { Uwall: } 0.57 ; 3 \mathrm{~cm} \mathrm{XPS}(0.03 \mathrm{w} / \mathrm{m}- \\
\mathrm{K})\end{array}$ & $\begin{array}{l}\text { Uwall: } 0.244 ; 10 \mathrm{~cm} \text { XPS }(0.03 \\
\text { w/m-K) }\end{array}$ \\
\hline & Uroof: 2.1; No Insulation & $\begin{array}{l}\text { Uroof: } 0.38 ; 10 \mathrm{~cm} \text { Rockwool } \\
(0.04 \mathrm{w} / \mathrm{m}-\mathrm{K})\end{array}$ & $\begin{array}{l}\text { Uroof: } 0.277 ; 14 \mathrm{~cm} \text { Rockwool } \\
(0.04 \mathrm{w} / \mathrm{m}-\mathrm{K})\end{array}$ \\
\hline & $\mathrm{U}_{\text {foundation }}: 1.70 ;$ No Insulation & $\begin{array}{l}\text { Ufound.: } 0.57 ; 4 \mathrm{~cm} \text { XPS }(0.04 \\
\text { w/m-K) }\end{array}$ & $\begin{array}{l}\text { Ufoundation: } 0.57 ; 4 \mathrm{~cm} \text { XPS } \\
(0.04 \mathrm{w} / \mathrm{m}-\mathrm{K})\end{array}$ \\
\hline Glass Type & $\begin{array}{l}\text { U: } 1.8 \mathrm{w} / \mathrm{m} 2 \mathrm{~K} ; 0.598 \text { SHGC; } \\
0.769 \text { Tvis }\end{array}$ & $\begin{array}{l}\text { U: } 1.8 \mathrm{w} / \mathrm{m} 2 \mathrm{~K} ; 0.598 \mathrm{SHGC} \text {; } \\
0.769 \text { Tvis }\end{array}$ & $\begin{array}{l}\text { U: } 0.799 \text { w/m2K; } 0.474 \text { SHGC; } \\
0.661 \text { Tvis }\end{array}$ \\
\hline Lighting Level & Fluorescent: $10.76 \mathrm{w} / \mathrm{m} 2$ & Fluorescent. $10.76 \mathrm{w} / \mathrm{m} 2$ & LED: $4.39 \mathrm{w} / \mathrm{m} 2$ \\
\hline Heating Type & Gas Heated Water Based Rad. & Gas Heated Water Based Radiator & Gas Heated Water Based Radiator \\
\hline Cooling Type & HVAC Air Conditioner & HVAC Air Conditioner & HVAC Air Conditioner (4.5 COP) \\
\hline Orientation & South & South & South \\
\hline \multirow[t]{2}{*}{ Glazing Ratio } & $30 \%$ & $30 \%$ & $30 \%$ \\
\hline & - & - & Exterior Venetian Blind Shading \\
\hline
\end{tabular}

\subsection{Energy Production}

Turkey has important potential of solar energy, solar energy is the most convenient way to generate energy in a high dense urban environment. Therefore, solar panels are used for energy production. Each panel has $17.3 \%$ module efficiency, which is highest performing one on the local market by the time. PV panels places on the south facing side of the roof and direct sun exposed part of the South, East and West facades on the date of June 21. By following described methodology and using listed inputs above, amount of site energy consumption and productions are calculated and compared. Since the source energy conversion factor various in each county, first site energy consumption and production is calculated and analyzed. Then, site energy consumptions of the least and highest performing alternatives are converted to source energy consumptions. Source energy conversation factor for natural gas is 1 and for electricity 2.36 in Turkey [69]. Results and analysis are presented in detail below.

\section{RESULTS and ANALYSIS}

This part presents the results of simulations and analysis of the findings. The simulation was performed via EnergyPlus simulation software. Energy consumption and production results are provided below.

Energy consumption results of all 24 urban textures which are made of six different building types are presented in Figure 7. Building types are simulated under small and large yard $\left(\mathrm{w}_{2}=2 \mathrm{w}_{1}\right)$ alternatives. For each yard alternative, minimum (1.3) and maximum (2.3) h/ $\mathrm{w}_{1}$ ratios simulated. In order to simplify, each building type subcategorized as A, B,C, and D-distances. Each urban textures are simulated for three different building envelopes: TS-825, Near-0, and Existing envelope. 


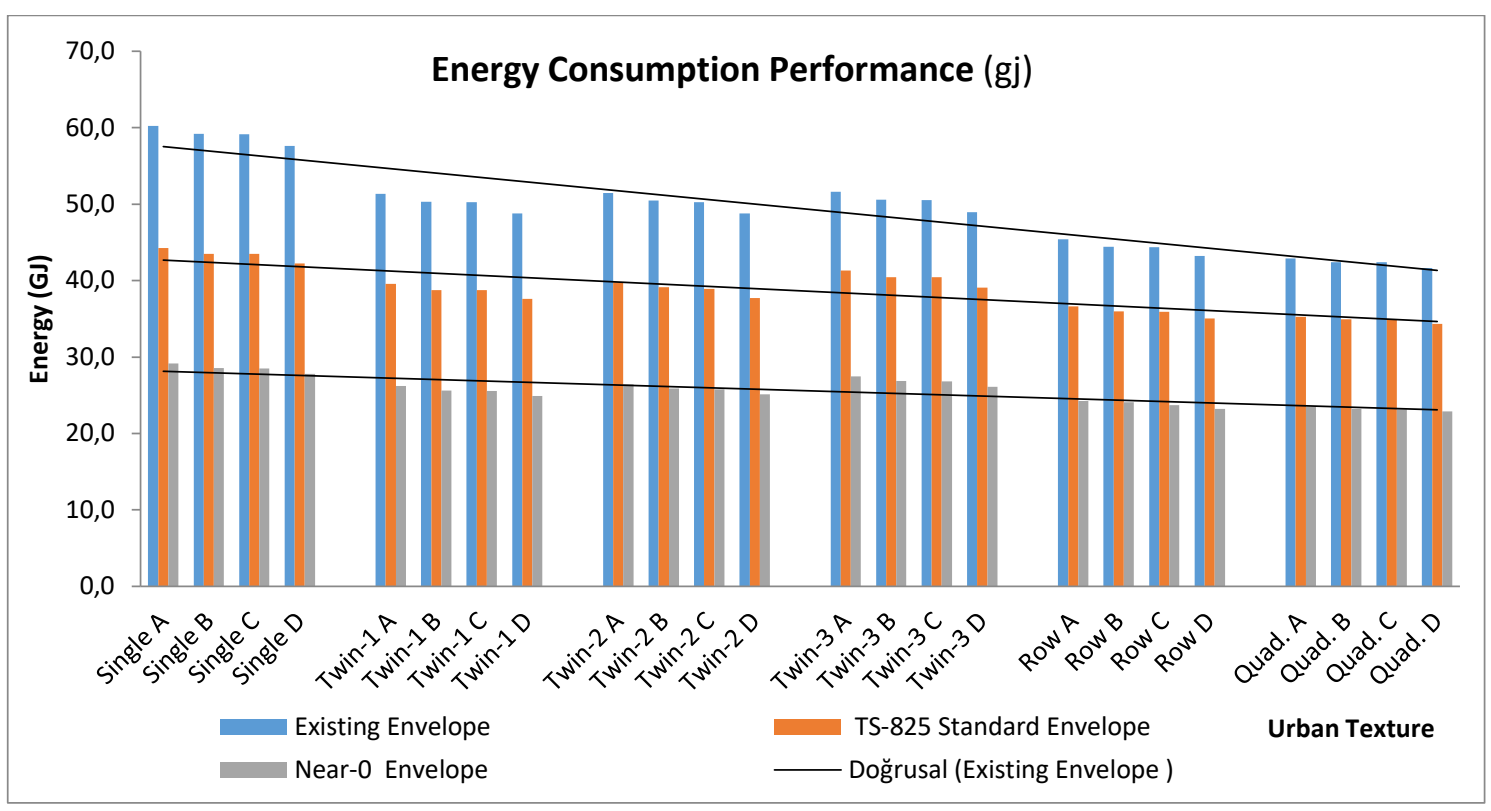

Figure 7. Energy consumption performance per unit (gj)

At first glance, Quad. apartment types consume least amount of energy while Single Standing (SS) building apartment types consume highest amount of energy. Row apartment performs as the second best alternative. Comparing all three twin alternatives, energy consumption of Twin- 1 is the minimum while Twin-3 is the exact opposite. TS-825 envelope building performs better than the Existing envelope; however, Near- 0 envelope reduces energy consumption significantly. In terms of energy consumption, from the order the lowest energy-consuming alternative to the highest value is D, C, B and A. Detailed analysis is presented below.

\subsection{Influence of Envelope on Energy Consumption}

Energy consumption performance of the Existing envelope for different building types and textures are presented below (Figure 8). Quadruple apartment type consumes least amount of energy per unit while Single S. apartment type consumes highest amount of energy. Comparing four different distance values, D-distances consume minimum and A-distances consume maximum amount of energy within all building types. Best performing one in all 24 different alternatives is Quad-D building type with $41.7 \mathrm{gj} / \mathrm{per}$ unit while the least performing one is Single-A alternative with $60.3 \mathrm{gj}$ energy consumption per unit. Single-A with Existing envelope consumes $44.7 \%$ of more energy comparing to Quad-D alternative.

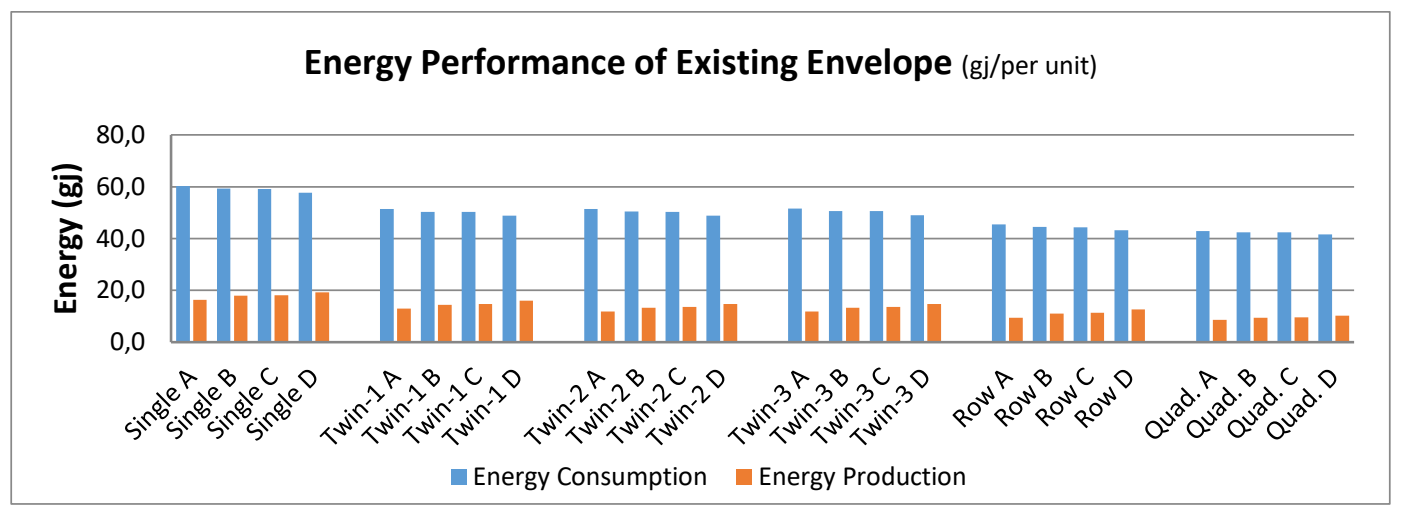

Figure 8. Energy performance of Existing envelope in 24 different building type and texture alternatives

The second envelope is TS-825 standard envelope. Energy consumption performance of TS-825 standard envelope for all 24 types and textures are illustrated in Figure 9. Similarly, Quadruple apartment type consumes least amount of energy per unit while Single S. apartment type consumes highest amount of 
energy. Comparing four different distance values presented similar results with Existing envelope. The best performing one in all 24 different alternatives is Quad-D building type with $44.3 \mathrm{gj} /$ per unit, compare to Existing envelope performance of $60.3 \mathrm{gj}$ energy consumption per unit. The least performing TS-825 envelope one is Single-A alternative with $34.4 \mathrm{gj}$ energy consumption per unit, compare to Existing envelope performance of 41.7 gj energy consumption per unit. In TS-825 envelopes, Single-A consumes $28.9 \%$ of more energy comparing to Quad-D alternative.

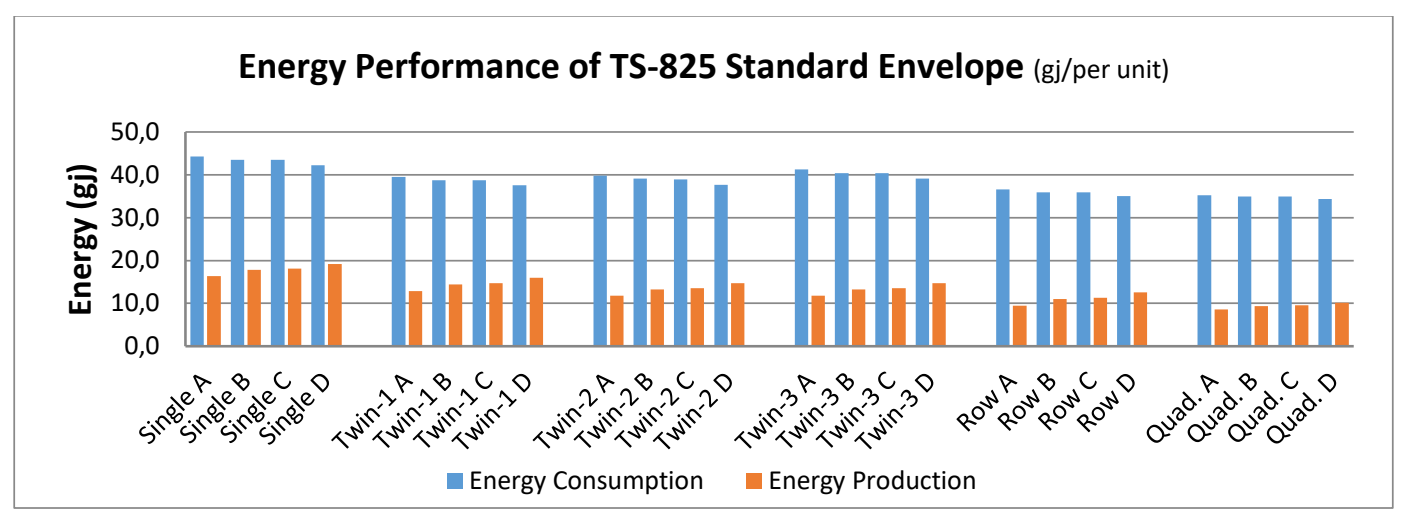

Figure 9. Energy performance of TS-825 envelope in 24 different building type and texture alternatives

The last one is Near-0 envelope. Energy consumption performance of Near-0 envelope for all alternatives are presented in Figure 10. The order of energy consumption for building types and distances resulted very similar to Existing envelope and TS-825 envelopes. Quadruple apartment type consumes least amount of energy per unit while Single S. apartment type consumes highest amount of energy. Comparing four different distance values, D-distance consumes minimum and A-distance consumes maximum amount of energy within all building types. Best performing Near-0 one in all 24 different alternatives is Quad-D building type with 22.9 gj/per unit, compare to TS-825 envelope performance of $44.3 \mathrm{gj} / \mathrm{per}$ unit energy. The least performing one is Single-A alternative with 29.2 gj energy consumption per unit, compare to TS825 envelope performance of $34.3 \mathrm{gj} / \mathrm{per}$ unit energy. Single-A texture with Near-0 envelope consumes $27.3 \%$ of more energy comparing to Quad-D alternative.

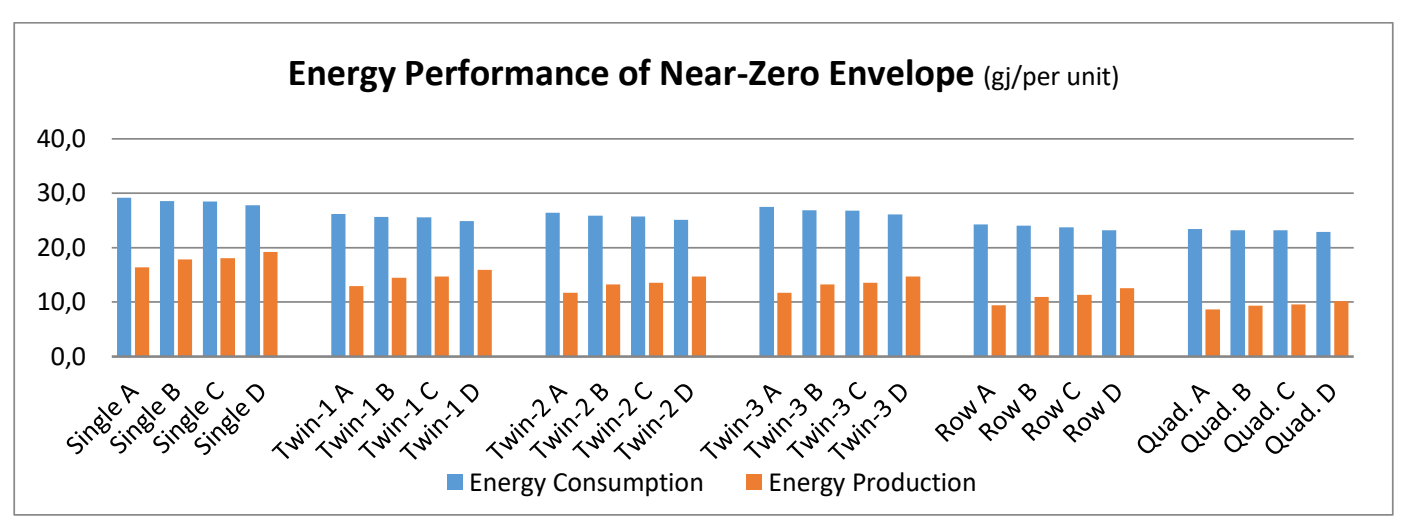

Figure 10. Energy performance of Near-Zero envelope in 24 different building type and texture alternatives

Detailed results of retrofitting Existing envelope to TS-825 and Near-0 envelopes summarized in Figure 11. The presented results for building types are the average value of four different distance alternatives (A, B, C, \& D). Near-0 envelope Quadruple apartment consumes $23.18 \mathrm{gj} /$ per unit energy which is the most conservative alternative while Near-0 envelope Single standing apartment consumes $28.51 \mathrm{gj} / \mathrm{per}$ unit.

The performance of retrofitted envelopes is compared with Existing envelopes. It is found that retrofits can save up to $51.7 \%$ energy. Although retrofits saved energy in all types of buildings, the saving rates within Single Standing apartment type is the highest. In this type, retrofitting Existing envelope to Near-0 saved $51.7 \%$ of energy while retrofitting it to TS-825 envelope saved to $26.6 \%$ of energy. However, retrofitting 
Existing envelope of Quad. apartment to Near-0 saved $45.2 \%$ of energy while retrofitting it to TS-825 envelope saved to $17.7 \%$ of energy.

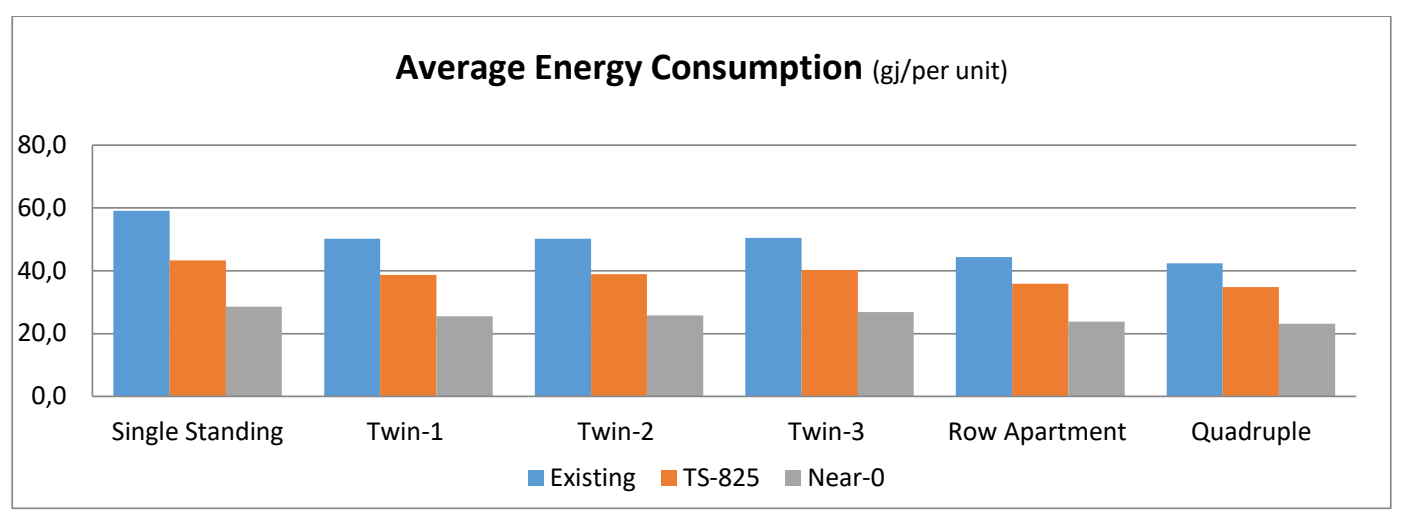

Figure 11. Average energy consumption of different building types and urban textures (Quadruple indicates the average energy consumption of Quadruple- $A, B, C, \& D$ for three different envelopes)

\subsection{Influence of Urban Texture on Energy Consumption}

In order to better understanding about the influence of urban texture on building energy consumption, energy consumption difference in all building types examined for each envelope types. Comparing best and worst performing of all 24 texture alternatives regardless of building type, a residential unit of SingleA consumes $60.25 \mathrm{gj}$ and a residential unit of Quad-D consumes $41.65 \mathrm{gj} / \mathrm{per}$ unit. In other words, SingleA alternative consumes $44.66 \%$ more energy comparing to Quad-D with Existing envelope. Retrofitting Existing envelope to TS-825 standard results a change in the influence of urban texture on energy consumption performance. With TS-825 envelope, a unit of Single-A consumes 44.7 gj while a Quad-D residential unit consumes $34.35 \mathrm{gj} / \mathrm{per}$ unit. This means, a Single-A residential alternative consumes $28.9 \%$ more energy comparing to Quad-D. Retrofitting TS-825 standard envelope to Near-0 proposal results also significant amount of reduction in energy consumption. A unit of Single-A consumes $29.16 \mathrm{gj} / \mathrm{per}$ unit while a Single-D residential unit consumes $22.9 \mathrm{gj} / \mathrm{per}$ unit energy. In here, Single-A consumes $27.34 \%$ more than Quad-D. These results clearly show that urban texture has a significant influence on energy consumption performance in all envelope alternatives.

In other words, retrofitting Existing envelope to TS-825 standard resulted a reduction from $44.6 \%$ to $28.9 \%$ in the difference while the retrofitting TS- 825 standard to Near-0 proposal resulted also a reduction from $28.9 \%$ to $27.34 \%$. Although the influence of urban texture on building energy consumption decreased with the envelope retrofits, it still generates $27.3 \%$ difference in energy consumption which is a significant number. The comparison until this point includes each and every building types and different $\mathrm{w}_{1} / \mathrm{w}_{2}$ and $\mathrm{h} / \mathrm{w}_{1}$ ratios. The results show that Quadruple apartment building type with large yard $\left(\mathrm{w}_{2} / \mathrm{w}_{1}=2\right)$ and $\mathrm{h} / \mathrm{w}_{1}=2.3$ performs best in terms energy consumption, while Single standing apartment building type with small yard $\left(\mathrm{w}_{1} / \mathrm{w}_{2}=1\right)$ and $\mathrm{h} / \mathrm{w}_{1}=1.3$ performs worst in all three envelope alternatives. Despite the fact that Quadruple apartment consumes minimum amount of energy, it is not wise to expect future cities or future of Istanbul consist of a certain residential type in a single urban texture.

Energy performance is not the only determent on housing choice. People always wants alternatives that reflects themselves. Some people may not want to live in a crowded apartment building or other may prefer to live in only south facing apartments. Therefore, it is important to understand each and every building types and their performance in different textures $\left(\mathrm{w}_{1} / \mathrm{w}_{2}\right)$ and $\left(\mathrm{h} / \mathrm{w}_{1}\right)$. Changing envelope also changes the energy consumption difference in each building types. Besides, change of texture also changes, the energy performance in each building types. It is obvious that energy consumption difference is minimum in Quad. apartment types with $2.46 \%$ in Near-0 alternative. The maximum energy consumption difference is Twin3 apartment alternative with 5.65 percent. The detailed difference showed in Figure 12. 


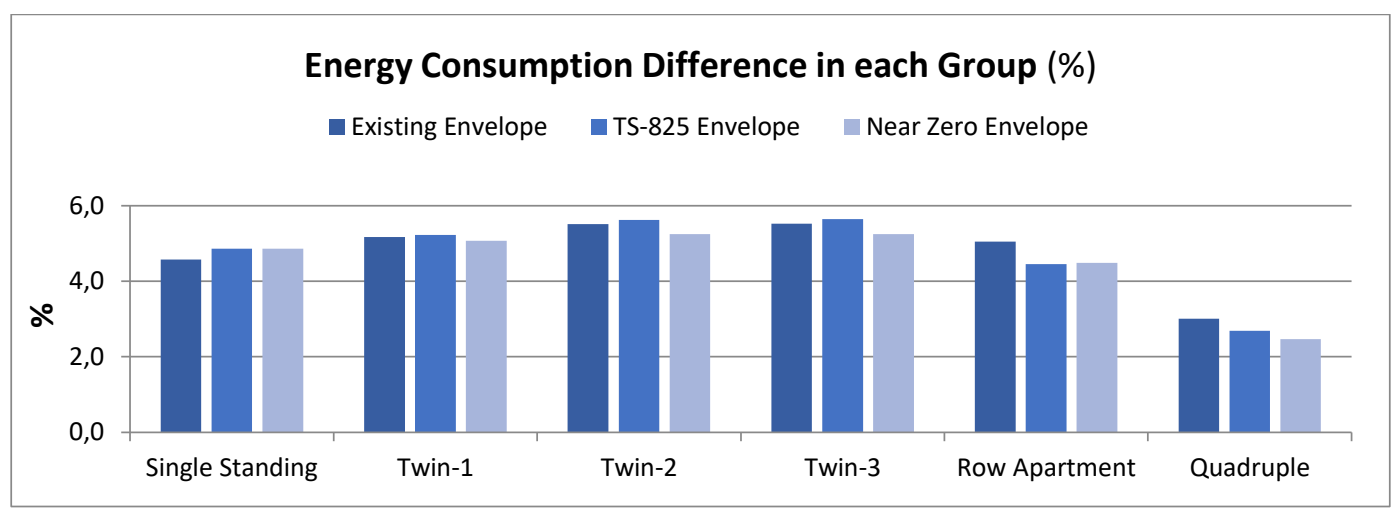

Figure 12. Average energy consumption difference due to urban texture alone

\subsection{Energy Production Performance Analysis}

In this part, the influence of urban texture on building energy production potential investigated. The result of energy production performance is illustrated in Figure 13. It is found that while Quad-D is the most productive alternative, Row-A is the least productive one. Although the number of residential units higher in Quad. apartment, the south facing roof area is also larger. Therefore, the Quad-D performs best of all. Second best performing one is the Single-D alternative. This graph is also clearly illustrates that $\mathrm{D}$-distance alternative produce highest amount of energy while A-distance produce minimum amount of energy. Cdistance produce slightly more energy than B-distance. Comparing lowest and highest energy production potential, Quad-D produce $115.96 \%$ more energy than Row-A alternative (Figure 13). It is found that there is $17.29 \%$ of energy production difference within Single Standing building type. The difference is 23.57\% for Twin-1 apartment, 25.29\% for Twin-2, 25.29\% for Twin-3, 33.49\% for Row, and 17.82\% for Quadruple apartment (Figure 14).

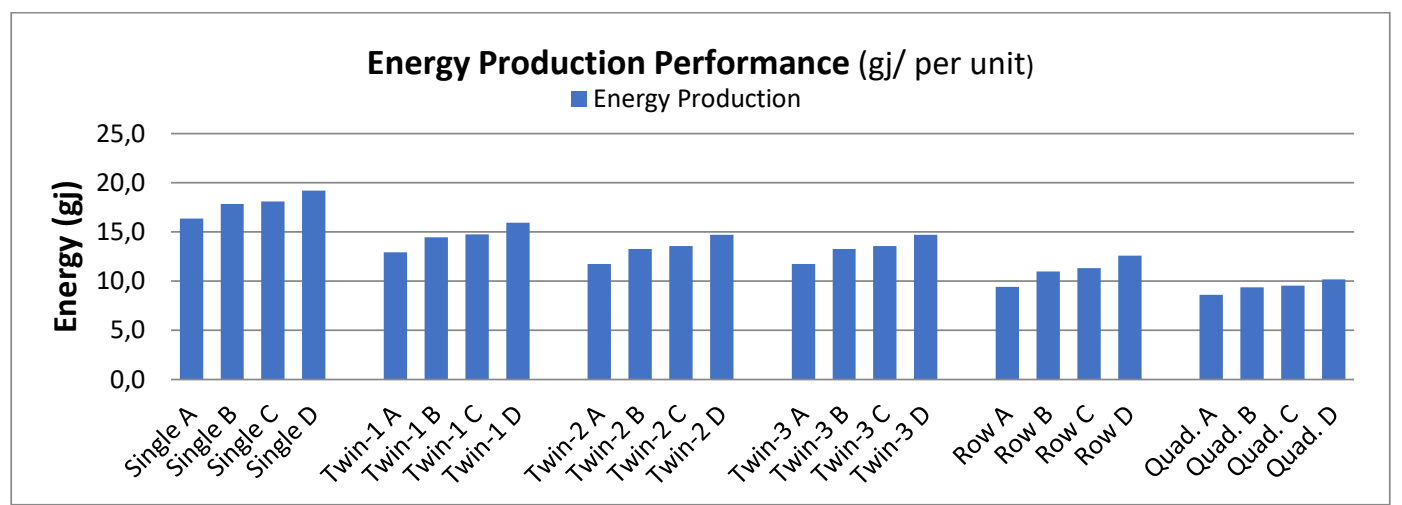

Figure 13. Influence of urban texture and building type on energy production performance

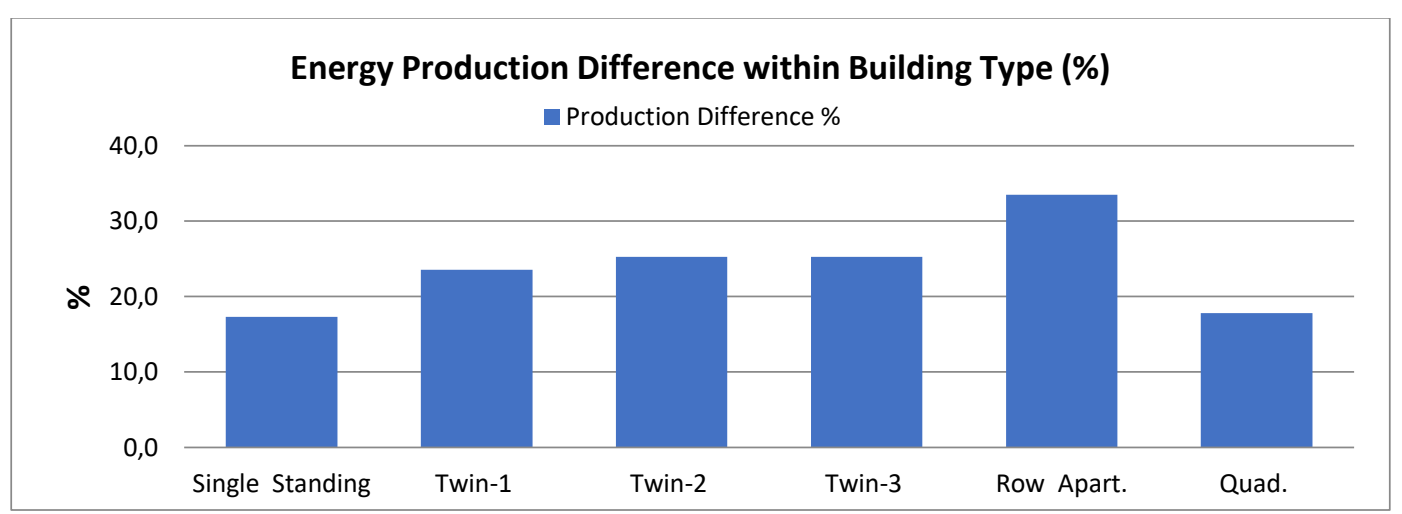

Figure 14. Energy production performance difference within each building type due to urban textures 


\section{DISCUSSION}

This section focuses on optimization of energy consumption and production potential of different urban textures. Figure 15 illustrates the energy performance of all 24 different textures under three envelope alternatives. It shows what percent of consumed site energy was generated from solar panel for each specific type. The results clearly shows that none of them achieves net-zero energy target; however, SingleD alternative with Near-0 envelope achieves generating $69 \%$ of its annual energy need. With the same envelope type, Quad-A is able to generate only $36.8 \%$ of its annual energy consumption. Although they both Near-0 envelope type, there is a significant performance difference due to urban texture and building type effect. Quad-A with Existing envelope is the least performing alternative which can generate $20.1 \%$ of its annual energy need. Comparing building types, it can be listed from best performing to least performing one as Quadruple, Row, Twin-1, Twin-2, Twin-3, and Single Standing apartment. The order is also applicable for other two envelope types. Comparing the distances, $\mathrm{D}$-distance always performs best while A-distance performs least.

Figure 15 presents the results of what percent of site energy consumption received from site produced energy. Calculation of source energy results shows that the least performing one, Quad-A texture with Existing envelope, achieves $25.1 \%$. On the other hand, Single-D texture with Near-0 envelope alternative, which is the highest performing one, is capable of achieving $83.9 \%$ near zero energy target.

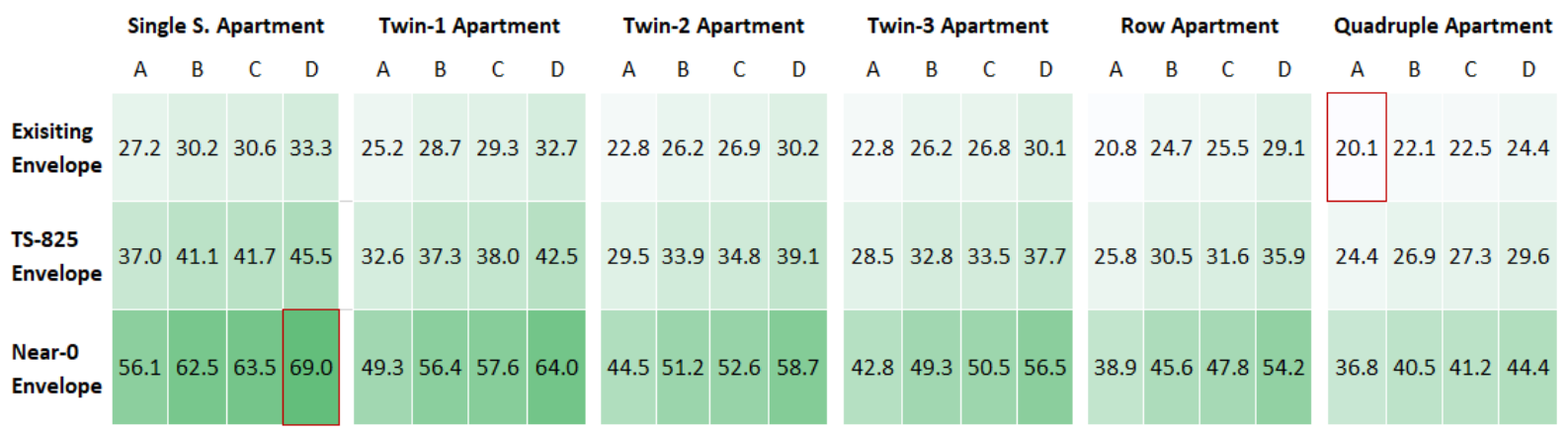

Figure 15. Comparison of site energy balance for all urban texture alternatives

\section{CONCLUSION}

The purpose of this study is to evaluate energy performance potential of residential buildings in order to decide the fitness of existing urban renewal progress with the goal of achieving zero-energy building goal of Turkey. For this aim, energy performance of residential buildings in Istanbul are simulated with building envelopes, building types, and urban textures. Evaluation of 24 different urban textures showed that it is not possible to achieve zero energy target with neither of all three building envelope alternatives. However, the best performing alternative achieves $69 \%$ site near-zero energy and $83.9 \%$ source near zero target with proposed Near-0 envelope. On the other hand, least performing alternative achieves only $20.1 \%$ site nearzero energy target and $25.1 \%$ source zero energy target.

Evaluation of building envelope energy consumption showed that although TS-825 standard provide a significant saving in energy consumption comparing to Existing envelope, its savings are far from enough achieving zero energy target. Best performing alterative texture of TS-825 envelope is capable of only achieving $45.5 \%$ site zero energy goal. Therefore, it is necessary to revise current TS-825 standard with more zero energy goal oriented version.

Another purpose of this study was to understand the influence of urban texture on building energy production and consumption. It is found that there are average $44.7 \%$ of energy consumption difference between best and least performing urban texture in Existing envelope while it is $28.9 \%$ for TS-825 standard and $27.3 \%$ for near-zero envelope. Urban texture also effects energy production performance, as well. There are $115.96 \%$ of difference in site energy production performance between best and worst performing 
one. This study clearly shows that urban texture has very significant influence on not only building energy consumption but also production performance in all building envelope types. Since Turkey is in the middle of a massive urban renewal process, along with building envelope, optimization of urban texture is also a very high potential for both energy savings and energy production point of views.

This study focuses on energy reduction and production with urban texture, energy production, building envelope, and lighting retrofits because they are mainly focus area of building design. Although these retrofits are not enough to achieve net-zero energy building target, it is proven a building can get $69.1 \%$ percent closer to site near-zero energy goal and $83.9 \%$ source near zero energy. There are also other ways to reduce energy consumption such as utilizing district heating systems. Additionally, potentials of wind and geothermal energy would extent achievement of zero energy target.

It should be noted that modifying urban texture comes with possible outcomes from urban transportation energy perspective. For a healthy conclusion when deciding energy efficient urban texture in Istanbul, building energy and transportation energy performances must optimized together. This study focused on building energy performance part, there is a potential for following studies to work on the relationship between urban texture and urban transportation performance.

\section{CONFLICTS OF INTEREST}

No conflict of interest was declared by the authors.

\section{REFERENCES}

[1] Becchio, C., Corgnati, S. P., Delmastro, C., Fabi, V., Lombardi, P., "The role of nearly-zero energy buildings in the transition towards Post-Carbon Cities", Sustain. Cities Soc., 27:324-337, (2016).

[2] https://www.iea-shc.org/data/sites/1/publications/t40a52-dc-tr1-30-net-zebs.pdf. Access date: 10.12.2018.

[3] Belussi, L., Barozzi, B., Bellazzi, A., Danza, L., Devitofrancesco, A., Fanciulli, C., Ghellere, M., Guazzi, G., Meroni, I., Salamone, F., Scamoni, F., Scrosati, C., "A review of performance of zero energy buildings and energy efficiency solutions”, J. Build. Eng., 25: 100772, (2019).

[4] Birinci, F., "Regulations and Fiscal Policy Factors (in term of Earthquake and Building Stock) Complicate Urban Renewal in Turkey (in Turkish)", Proceedings of the II.Turkey Earthquake and Seismology Conference, Hatay, Turkey, 2:3-13, (2013)

[5] AFAD, "Disaster Management and Natural Disaster Statistics in Turkey", Turkey Disaster and Emergency Management Authority, Ankara, 46-47, (2018).

[6] Bibbee, A., Gönenç, R., Jacobs, S., Konvitz, J., Price, R, "Economic Effects of the 1999 Turkish Earthquakes: An Interim Report", Organisation for Economic Co-operation and Development, (2000).

[7] Pacific Consultants International / OYO Corporation, "The Study on A Disaster Prevention / Mitigation Basic Plan In Istanbul Including Microzonation In The Republic of Turkey", Istanbul, (2002).

[8] The Ministry of Environment and Urbanization, “2018-2022 Stratejik Plan”, Ankara, (2017).

[9] http://www.iea.org/statistics/statisticssearch/report/?year=2015\&country=TURKEY\&product= Indicators. Access date: 24.7.2018. 
[10] http://www.iea.org/statistics/statisticssearch/report/?year=2015\&country=TURKEY\&product= Balances. Access date: 27.7.2018.

[11] UNFCCC, "Republic of Turkey - Intended Nationally Determined Contribution", United Nations, (2015).

[12] The Ministry of Development of the Republic of Turkey, "Report on Turkey's Initial Steps towards the Implementation of the 2030 Agenda for Sustainable Development", Ankara, (2016).

[13] The Ministry of Environment and Urbanization of Turkey, "National Climate Change Action Plan", Ankara, (2011).

[14] Official Gazette, "Building Energy Performance Regulation”, Say1: 27075, Ankara, (2008).

[15] Official Gazette, "Renewable Energy Resource Area Regulation", Say1: 29852, Ankara, (2016).

[16] Official Gazette, "Regulation on Searching for Improvements on Energy Resources and Efficiency Energy Usage", Say1: 28097, (2011).

[17] Kocabas, A., "The Emergence of Istanbul's Fifth Urban Planning Period: A Transition to Planning for Sustainable Regeneration?”, J. Urban Technol., 12(2): 27-48, (2005).

[18] Kocabas, A., "The transition to low carbon urbanization in Turkey: Emerging policies and initial action”, Habitat Int., 37:80-87, (2013).

[19] Directory of Butget and Fiscal Control, "Mid-Term Fiscal Report of 2019-2021", Republic of Turkey Ministry of Treasury and Finance, Ankara, (2018).

[20] Presidency of Strategy and Budget, “11.Development Plan of Turkey for 2019-2023”, Ankara, (2019).

[21] Uzun, B., Simsek, N. C., "Upgrading of illegal settlements in Turkey; the case of North Ankara Entrance Urban Regeneration Project”, Habitat Int., 49:157-164, (2015).

[22] Uzun, B., Çete, M., Palancioğlu, H. M., "Legalizing and upgrading illegal settlements in Turkey", Habitat Int., 34(2):204-209, (2010).

[23] Güzey, Ö., "Urban regeneration and increased competitive power: Ankara in an era of globalization", Cities, 26(1):27-37, (2009).

[24] Demirli, M. E., Ultav, Z. T., Demirtaş-Milz, N., "A socio-spatial analysis of urban transformation at a neighborhood scale: The case of the relocation of Kadifekale inhabitants to TOKİ Uzundere in İzmir", Cities, 48:140-159, (2015).

[25] Güzey, Ö., "The last round in restructuring the city: Urban regeneration becomes a state policy of disaster prevention in Turkey", Cities, 50:40-53, (2016).

[26] TS825, "Thermal insulation requirements for buildings", Turkish Standats Institution, Ankara, (2013).

[27] Turkey Ministry of Environment and Urbanization, “2017 Annual Report”, Ankara, (2018). 
[28] Mangan, S. D., Oral, G. K., "Assessment of residential building performances for the different climate zones of Turkey in terms of life cycle energy and cost efficiency", Energy Build., 110:362$376,(2016)$.

[29] Kalaycığlu, E., Yılmaz, A. Z., "A new approach for the application of nearly zero energy concept at district level to reach EPBD recast requirements through a case study in Turkey", Energy Build., 152:680-700 (2017).

[30] Coutts, A. M., Beringer, J., Tapper, N. J., "Impact of Increasing Urban Density on Local Climate: Spatial and Temporal Variations in the Surface Energy Balance in Melbourne, Australia", J. Appl. Meteorol. Climatol., 46(4):477-493, (2007).

[31] Strømann-Andersen, J., Sattrup, P.A., "The urban canyon and building energy use: Urban density versus daylight and passive solar gains", Energy Build., 43(8): 2011-2020, 2011.

[32] Tereci, A., Kesten, D., Eicker, U., "The Impact of the Urban Form on Heating, Cooling and Lighting Demand of Cities", Proceedings of the 1. International Conference on Sustainable Urbanization, Hong Kong, China, 2010.

[33] Niachou, K., Livada, I., Santamouris, M., "Experimental study of temperature and airflow distribution inside an urban street canyon during hot summer weather conditions. Part II: Airflow analysis", Build. Environ., 43(8):1393-1403, (2008).

[34] Santamouris, M., Papanikolaou, N., Livada, I., Koronakis I., Georgakis, C., Argiriou, A., Assimakopoulos, D. N., "On the impact of urban climate on the energy consumption of buildings", Sol. Energy, 70(3):201-216, (2001).

[35] Grosso, M., "Urban form and renewable energy potential”, Renew. Energy, 15(1-4):331-336, (1998).

[36] Ali-Toudert, F., Mayer, H., "Numerical study on the effects of aspect ratio and orientation of an urban street canyon on outdoor thermal comfort in hot and dry climate", Build. Environ., 41(2):94-108, (2006).

[37] Johansson, E., "Influence of urban geometry on outdoor thermal comfort in a hot dry climate: A study in Fez, Morocco", Build. Environ., 41(10):1326-1338, (2006).

[38] Oke, T. R., "Street design and urban canopy layer climate", Energy Build., 11(1-3):103-113, (1988).

[39] Laski. L., Schellekens. S., "The State of World Population 2007 Youth Suplement", United Nations, (2007).

[40] UN Department of Economic and Social Affairs, "World Urbanization Prospects The 2011 Revision", United Nations, New York, (2012).

[41] Oke T. R., "The energetic basis of the Urban Heat Island”, Q. J. R. Meteorol. Soc., 108(455):124, (1982).

[42] Hassid, S., Santamouris, M., Papanikolaou, N., Linardi, A., Klitsikas, N., Georgakis, C., Assimakopoulos, D. N., "The effect of the Athens heat island on air conditioning load", Energy Build., 32(2): 131-141, (2000). 
[43] Taha, H., Akbari, H., Rosenfeld, A., Huang, J., "Residential cooling loads and the urban heat island - the effects of albedo", Build. Environ., 23(4):271-283, (1988).

[44] Fung, W. Y., Lam, K. S., Hung, W. T., Pang, S. W., Lee, Y. L., "Impact of urban temperature on energy consumption of Hong Kong", Energy, vol. 31(14):2623-2637, (2006).

[45] Loga, T., Stein, B., Diefenbach, N., "TABULA building typologies in 20 European countriesMaking energy-related features of residential building stocks comparable", Energy Build., 132:4 $12,(2016)$.

[46] Dascalaki, E. G., Droutsa, K. G., Balaras, C. A., Kontoyiannidis, S., "Building typologies as a tool for assessing the energy performance of residential buildings - A case study for the Hellenic building stock", Energy Build., 43(12):3400-3409, (2011).

[47] Kragh, J., Wittchen, K. B., "Development of two Danish building typologies for residential buildings", Energy Build., 68:79-86, (2014).

[48] Ballarini, I., Corgnati, S. P., Corrado, V., "Use of reference buildings to assess the energy saving potentials of the residential building stock: The experience of TABULA project", Energy Policy, 68:273-284, (2014).

[49] Ballarini, I., Corrado, V., Madonna, F., Paduos, S., Ravasio, F., "Energy refurbishment of the Italian residential building stock: energy and cost analysis through the application of the building typology”, Energy Policy, 105: 148-160, (2017).

[50] Filogamo, L., Peri, G., Rizzo, G., Giaccone, A., "On the classification of large residential buildings stocks by sample typologies for energy planning purposes”, Appl. Energy, 135:825-835, (2014).

[51] Horváth, M., Kassai-Szoó, D., Csoknyai, T., "Solar energy potential of roofs on urban level based on building typology", Energy Build., 111:278-289, (2016).

[52] Beyaztas, H., Oral, G. K., "Evaluating Energy Performance of Facades Related to Urban Texture", in International Conferance on Building Envelope Systems and Technologies, Istanbul, 36-44 (2017).

[53] Beyaztas, H., Oral, G. K., "Investigating the Influence of Urban Texture and Building Typology on Rooftop and Facades Energy Production (in Turkish)", Proceedings of 3. National Building Physics and Environmental Control Congress , Istanbul, 287-296 (2018).

[54] Daniels, K., Hammann, R. E., "Energy Design for Tomorrow / Energy Design für morgen”, Axel Menges, Stuttgart, (2009)

[55] Kapsalaki, M., Leal, V., "Recent progress on net zero energy buildings", Adv. Build. Energy Res., 5(1):129-162, (2011).

[56] Lovell, H., "The role of individuals in policy change: the case of UK low-energy housing", Environ. Plan. C Polit. Sp., 27(3):491-511, (2009).

[57] California Energy Commission, "Integrated Energy Policy Report (Summary)", 27-28, California, United States, (2007).

[58] European Commission, "Directive 2010/31/EU OF the European Parliment and of the Council of 19 May 2010 on the energy performance of buildings (recast)", Off. J. Eur. Union, (2010). 
[59] Executive Order, "Federal Leadership in Environmental, Energy, and Economic Performance", Order no: 13514, United States, (2009).

[60] National Institute of Building Sciences, "A Common Definition for Zero Energy Buildings", Department of Energy, United States, (2015).

[61] European Commission, "Directive 2010/31/EU of the Europan Parliament and of the Council of 19 May 2010 on the energy performance of buildings (recast)," Off. J. Eur. Union, L 153/13, (2010).

[62] City Planning Department of Istanbul, “1/100.000 Scale Istanbul Environmental Plannig Report”, Istanbul, (2009).

[63] http://episcope.eu/index.php?id=169. Access date: 15.10 .2019 .

[64] Ganiç, N., Yılmaz, A. Z., "Adaptation of the cost optimal level calculation method of Directive 2010/31/EU considering the influence of Turkish national factors", Appl. Energy, 123:94-107, (2014).

[65] http://webtool.building-typology.eu/\#bm. Access date: 15.10.2019.

[66] TUIK, "Population and Housing Census", Turkish Statistical Institute, Ankara, (2011).

[67] https://biruni.tuik.gov.tr/yapiizin/giris.zul. Access date: 16.5.2018.

[68] http://www.gazbir.org.tr/uploads/page/2017-Yili-Dogal-Gaz-Dagitim-Sektoru-Raporu.pdf. Access date: 22.5.2018.

[69] Official Gazette, "Declaration of National Building Energy Performance Calculation Methodology", Ankara, (2010). 